\title{
Radio-Echo Sounding Over Polar Ice Masses
}

\author{
Robert G. Bingham* and Martin J. Siegert ${ }^{\dagger}$ \\ Centre for Polar Observation and Modelling, Bristol Glaciology Centre, School of Geographical Sciences, \\ University of Bristol, University Road, Bristol, BS8 1SS \\ Email: rgbi@bas.ac.uk \\ *Now at: British Antarctic Survey, Natural Environment Research Council, High Cross, \\ Madingley Road, Cambridge, CB3 0ET \\ †Now at: Centre for Polar Observation and Modelling, School of GeoSciences, University of Edinburgh, \\ Grant Institute, King's Buildings, West Mains Road, Edinburgh, EH9 3JW
}

\begin{abstract}
Radio-echo sounding (RES) constitutes the principal means by which glaciologists investigate the subsurface properties of the polar ice sheets and ice caps. Developed in the 1960s as a method for locating and mapping the subglacial interface beneath extensive regions of icecovered terrain, thereby to constrain ice volume and morphology, it was quickly discovered that RES supplies numerous additional cryospheric parameters, including strong reflectors derived from subglacial lakes, and isochronous internal reflectors derived from burial of snow deposition events. Soon after its establishment, RES was integrated into long-range aircraft primarily to image the bed across Antarctica and Greenland (1960s/1970s). More recent airborne campaigns (1980s/1990s), while supplementing this coverage and extending to the ice caps of the High Arctic, have utilised only short-range aircraft, and were designed explicitly to support specific scientific studies, such as locating optimal sites for deep ice-coring, constraining the dimensions of subglacial lakes, or resolving internal layers for studies of ice sheet mass balance, form and flow. In parallel with these developments, ground-based (over-snow) RES equipment has also been used to investigate the englacial and subglacial conditions at a number of key locations across the polar ice sheets. This article discusses the many scientific advances which have resulted from these efforts, and offers recommendations for future developments in terms of (i) reanalysis of existing data and (ii) suggestions for future RES campaigns.
\end{abstract}

\section{Introduction}

Radio-echo sounding (RES) is a technique through which scientists investigate the subsurface properties of polar ice masses. RES, also known as ice-penetrating radar (IPR) or radar sounding, primarily exploits electromagnetic (EM) waves in the HF/VHF (megahertz) bands, to which, it was discovered in the late 1950s, cold ice is largely transparent. Prior to this discovery, glaciological calculations reliant upon such basic quantities as ice thickness and volume were based on a very limited and widely-spaced set of active seismic measurements, which were highly labor-intensive to obtain; and the englacial properties of ice sheets and ice caps remained enigmatic. Today, RES comprises an efficient method for the collection of a wide range of fundamental subglacial and englacial data from polar ice masses, complementing the extensive array of observations on surface elevation and flow that are now obtained using satellite remote sensing methods (Bindschadler, 1998). To constrain these boundary conditions is important, because it is widely recognised that ice sheets and ice caps fluctuate in response to climate change, thereby impacting significantly on sea levels; and our ability to predict future behaviour is fundamentally dependent upon the accurate determination of past and present ice volumes, subglacial morphology, accumulation and melting rates, and rates of ice flow.

RES equipment comprises a transmitter that emits EM waves and a receiver that records their reflections (or 'echoes') from any surfaces where there is a contrast in dielectric properties. Over ice sheets and ice caps, the most common reflectors constitute the ice surface, the basal interface, and englacial (internal) layers; although additional features such as subglacial lakes, subsurface crevasses and thermal boundaries can also be discerned.

RES apparatus can be mounted either on to airborne or ground-based (over-snow) platforms. For comprehensive studies of ice sheets and ice caps over scales of $10 \mathrm{~s}$ to $100 \mathrm{~s}$ of $\mathrm{km}$, airborne RES constitutes the most logistically feasible and efficient mechanism for 


\section{Journal of Environmental and Engineering Geophysics}

gathering subsurface data. In particular, airborne RES programmes conducted over Antarctica and Greenland since the 1960s have revolutionised our understanding of the englacial and subglacial conditions beneath the surfaces of these vast polar ice sheets. For some investigations however, for example in smaller-scale $(\mathrm{km}$ to $10 \mathrm{~s}$ of $\mathrm{km})$ studies, surveys in regions of complex subglacial topography (i.e., outlet glaciers), or simply in an attempt to reduce costs associated with the expensive deployment of aircraft, ground-based RES (a.k.a., Ground-Penetrating Radar, GPR) has been preferred.

In this article, we build upon recent reviews of RES in glaciology (Plewes and Hubbard, 2001; Dowdeswell and Evans, 2004) by focusing on the current state of the field in RES over polar ice masses, i.e., the Antarctic and Greenland Ice Sheets, and the large ice caps of the Canadian and Eurasian High Arctic. Over these vast ice masses the majority of RES has been conducted from airborne platforms, hence this review will tend to focus on airborne studies; however, we will also reference significant results and findings that have arisen from associated ground-based studies. In particular, we consider the types of data that have been generated by RES and the issues to which they have been applied to date; and based on these discussions we propose some future directions for RES surveying over the polar ice sheets and ice caps.

\section{Subglacial Exploration and Investigations}

\section{Subglacial Topography and Ice-Mass Morphology}

Airborne RES techniques were initially developed to locate the bed reflector beneath continental-scale areas of ice-covered terrain, thereby to constrain subglacial topography for the determination of ice-mass morphology (Evans and Robin, 1966). The first wideranging, comprehensive and systematic airborne RES surveys designed for this purpose were conducted between 1967 and 1979 over the 12.4 million $\mathrm{km}^{2}$ Antarctic Ice Sheet by a consortium of the University of Cambridge's Scott Polar Research Institute (SPRI), the U.S. National Science Foundation (NSF) and the Technical University of Denmark (TUD). These "SPRINSF-TUD" surveys used a $60 \mathrm{MHz}$ pulsed instrument, designed for optimal ice penetration and bed detection beneath several $\mathrm{km}$ of ice, mounted onto a U.S. C130 Hercules long-range aircraft, which facilitated surveying deep in the ice-sheet interior $100 \mathrm{~s}$ of $\mathrm{km}$ from the nearest scientific support camps (Bailey et al., 1964; Gudmandsen, 1969; Robin et al., 1977; Siegert, 1999).

The SPRI-NSF-TUD Antarctic RES surveys proved seminal; covering much of the continental ice sheet at a grid spacing of 50-100 km, imaging the bed along $86 \%$ of the $400,000 \mathrm{~km}$ of tracks flown, and achieving an areal coverage which has never subsequently been matched (Siegert, 1999). The 70,000 bed echoes gathered in the campaign were used to produce the first map of Antarctic subglacial topography (Drewry, 1983), and showed for the first time that the ice was, on average, $2.5 \mathrm{~km}$ thick, reached a maximum depth of $4.7 \mathrm{~km}$, and had a volume of $\sim 30 \mathrm{mil}-$ lion $\mathrm{km}^{3}$ which, if melted completely, would raise global sea level by $\sim 60 \mathrm{~m}$ (Dowdeswell and Evans, 2004). The survey findings were also instrumental in the conceptual division of the ice sheet into two components: the 'continental' East Antarctic Ice Sheet (EAIS), found to be grounded mainly above modern sea level and therefore considered relatively stable, and the 'marine' West Antarctic Ice Sheet (WAIS), found to be grounded mainly below modern sea level, and therefore considered potentially prone to rapid flotation and collapse in response to rising sea levels and/or thinning (Mercer, 1978). Twenty-seven years after the SPRI-NSF-TUD RES campaigns were discontinued in 1979, many sectors of the continental ice sheet that it surveyed have never been revisited. The data gathered remains commonly exploited in contemporary studies, and the scientific hypothesis of WAIS instability that it instituted remains at the heart of many scientific programmes in Antarctica.

Subsequent airborne RES campaigns in Antarctica, while implicitly incrementally supplementing the continental coverage of subglacial topography, have all explicitly been directed to support specific scientific activities, such as searching for optimal sites to locate deep ice cores, or obtaining high resolution records of internal layering which can be used to investigate ice dynamics and ice sheet evolution (a theme we investigate in more detail later in this paper). Examples include detailed site surveys associated with the European Project for Ice Coring (EPICA) deep ice-core sites at Dome C (Tabacco et al., 1999; Remy and Tabacco, 2000; Forieri et al., 2004) and Dronning Maud Land (Steinhage et al., 1999; Steinhage et al., 2001), East Antarctica; and extensive surveys of the Siple Coast ice streams (Retzlaff et al., 1993; Blankenship et al., 2001; Peters et al., 2005), Ellsworth Land, Marie Byrd Land, and the Antarctic Peninsula (see Lythe et al., 2001, and references therein), designed to obtain detailed input for numerical modelling investigations of ice streams and potential WAIS instability. These surveys have all utilized smaller, more economical, short and mediumrange aircraft (e.g., DeHavilland Twin Otter, Dornier Do228-101, Lockheed P-3); and, in addition to 'filling in' some of the 'gaps' left by the SPRI-NSF-TUD surveys, have delivered high-resolution records of subglacial topography across a number of key sites in Antarctica. 


\section{Bingham and Siegert: Radio-Echo Sounding Over Polar Ice Masses}

In 2001, RES records of ice thickness in Antarctica were collated and incorporated into a new database (BEDMAP; Bedrock Mapping Project) held at the British Antarctic Survey. This database combined determinations of the bed reflector from airborne RES with those from various ground-based RES surveys (e.g., Tabacco et al., 1998; Gades et al., 2000) as well as additional measurements from seismics, gravimetry and ice coring (Lythe et al., 2001). Containing over 2 million ice thickness measurements, BEDMAP was used to generate an updated digital elevation model (DEM) of Antarctic subglacial topography over a grid resolution of $5 \mathrm{~km}^{2}$ (Lythe et al., 2001). This latest version of Antarctic subglacial topography, when combined with surface elevation data yielded by satellite altimetry, suggests that Antarctica presently supports 25.7 million $\mathrm{km}^{3}$ of ice, and the DEM constitutes an integral boundary condition for recent estimates of satellitederived mass balance change across Antarctica (Arthern and Hindmarsh, 2003; Rignot et al., 2004).

Nevertheless, in many regions of Antarctica, most notably in remote, interior regions of the EAIS, the basal reflector remains very poorly constrained by empirical observations, often restricting the ability of numerical models to reproduce significant facets of ice sheet form and flow in response to climatic stimuli. RES efforts since 2001, and the generation of the first iteration of BEDMAP, have therefore continued to image the bed in regions of particular data paucity, gradually enhancing our knowledge of the subglacial topography beneath hitherto non-surveyed regions. Significant airborne surveys which have added to our knowledge of basal topography since 2001 therefore include: (i) investigations over Coats Land, East Antarctica, from which the Bailey and Slessor Ice Streams contribute significant mass to the FilchnerRonne Ice Shelf from a highly-overdeepened basin (Rippin et al., 2003a; Rippin et al., 2004); (ii) surveys over the Amundsen Sea sector of West Antarctica containing the rapidly thinning Thwaites and Pine Island basins (Thomas et al., 2004; Holt et al., 2006; Vaughan et al., 2006); (iii) traverses from the Transantarctic Mountains into interior East Antarctica, including the South Pole region (Davis et al., 2004; Studinger et al., 2004a); and (iv) expanded coverage over Dronning Maud Land in the vicinity of the EPICA Kohnen ice-coring site (Steinhage et al., 2001; Ferraccioli et al., 2005). Coordinated over-snow RES surveys conducted as part of the International Trans-Antarctic Scientific Expedition (ITASE) are also adding to our knowledge of subglacial conditions across Antarctica (Welch and Jacobel, 2003). The contemporary RES coverage of Antarctica is shown in Fig. 1a.
Over Greenland, airborne RES surveys conducted throughout the 1970s by the Technical University of Denmark, again using a $60 \mathrm{MHz}$ system, covered $\sim 30,000 \mathrm{~km}$ of flight track, and revealed that the ice sheet had a mean ice thickness of $1.4 \mathrm{~km}$, a maximum depth of $\sim 3 \mathrm{~km}$, and a total ice volume of $\sim 2.83$ million $\mathrm{km}^{3}$ (Gudmandsen, 1969; Bogorodskiy et al., 1985; Létreguilly et al., 1991). Subsequent surveys, as in Antarctica, were more regionally concentrated, and largely associated with the search for optimal deep icecoring sites (Hodge et al., 1990; Jacobel and Hodge, 1995; Dahl-Jensen et al., 1997; Hvidberg et al., 1997; Hempel et al., 2000). However, since 1993, a wideranging airborne RES survey of the Greenland Ice Sheet, using a $150 \mathrm{MHz}$ system designed and operated by researchers at the University of Kansas, under the auspices of the US NASA PARCA (Program for Arctic Regional Climate Assessment) initiative, has taken in over $105,000 \mathrm{~km}$ of flight track, surveying $\sim 80 \%$ of the ice sheet with an average along-track spacing of $150 \mathrm{~m}$ (Gogineni et al., 2001) (Fig. 1b-c). This extremely highquality and comprehensive dataset has been used to generate updated DEMs of the subglacial topography beneath the Greenland Ice Sheet which, when combined with satellite altimetry measurements, yields an ice volume of 2.85 million $\mathrm{km}^{3}$, whose wholesale melting could cause global sea level to rise by $\sim 7 \mathrm{~m}$ (Bamber et al., 2001, 2003). There do, however, remain regions of Greenland, particularly across many of its outlet glaciers, where thick, warm ice tends to scatter the radar signal and the bed remains obscured, and efforts are ongoing to develop methods to image the bed in these most challenging sectors of the ice sheet (Braaten et al., 2002). This is especially important in the light of recent satellite observations of significant accelerations of many of Greenland's outlet glaciers (Rignot and Kanagaratnam, 2006).

Elsewhere in the Arctic, RES has also been used to image the bed and map the subglacial topography of selected ice caps in the Canadian Arctic islands (Evans and Robin, 1966; O'Neil and Jones, 1975; Narod et al., 1988; Dowdeswell et al., 2004) and the Eurasian archipelagos of Svalbard (Drewry et al., 1980; Macheret and Zhuravlev, 1982; Dowdeswell et al., 1984), Franz Josef Land (Dowdeswell et al., 1999) and Severnaya Zemlya (Bogorodskiy et al., 1985; Dowdeswell et al., 2002) (Fig. 1). These surveys provide vital morphological boundary conditions for modelling cryosphereclimate interactions across the High Arctic, where the smaller, and therefore more rapidly responsive, ice masses may contribute more mass to sea level rise over the next century than the major ice sheets. However, RES surveys have not, to date, been conducted over all of the Canadian Arctic ice caps, nor over the $23,600 \mathrm{~km}^{2}$ North Ice Cap, Novaya Zemlya. 
Journal of Environmental and Engineering Geophysics

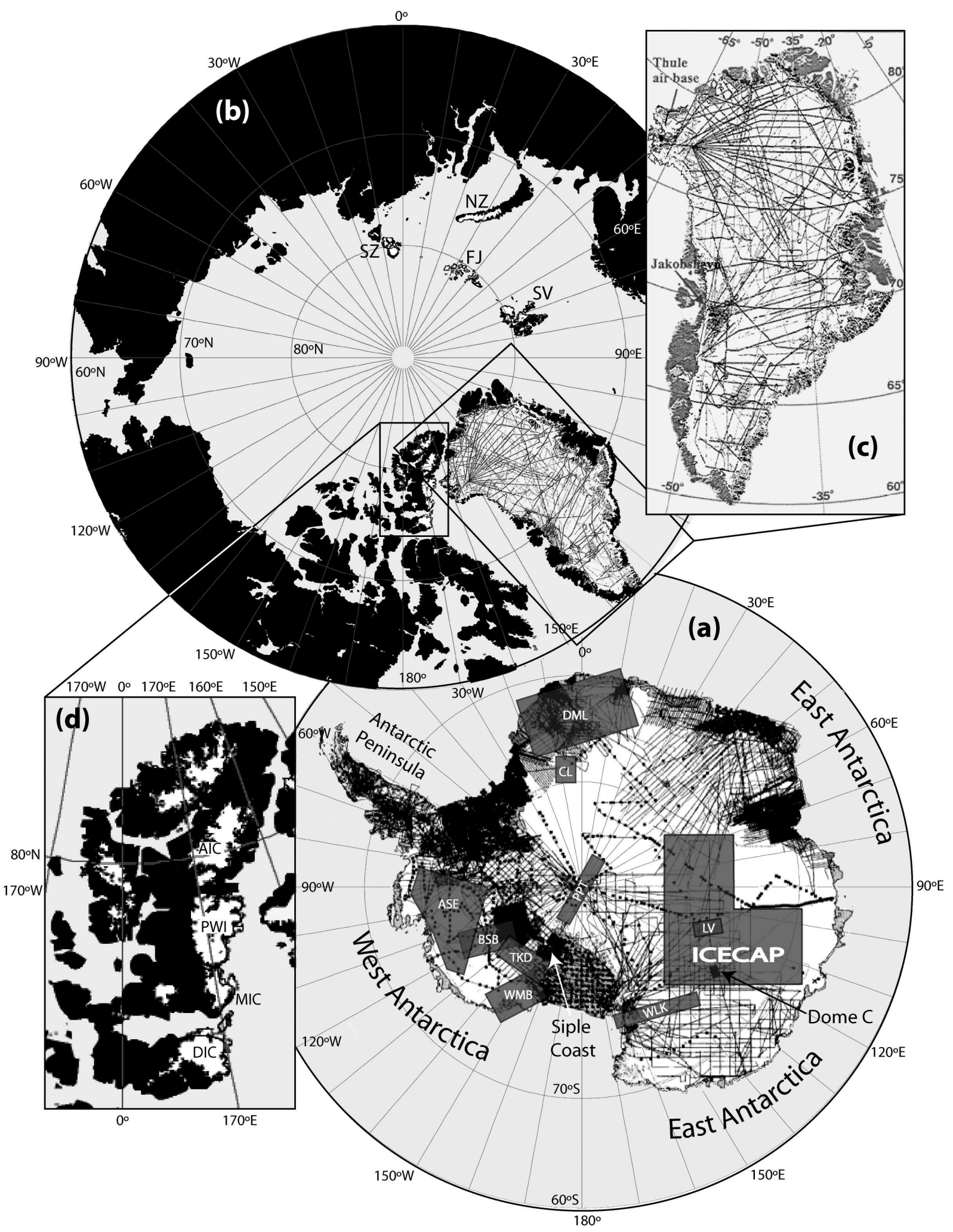

Figure 1. RES coverage over the polar regions. (a) Newly surveyed regions of Antarctica (shaded in grey) overlaid over the existing coverage according to BEDMAP (black lines; after Lythe et al., 2001). DML = Dronning Maud Land; CL = Coats Land; ASE = Amundsen Sea Embayment; BSB = Byrd Subglacial Embayment; TKD = Trunk of Bindschadler Ice Stream (formerly Ice Stream D); WMB = Western Marie Byrd Land; PPT = Pensacola-Pole Transect; LV = Lake 
Bingham and Siegert: Radio-Echo Sounding Over Polar Ice Masses

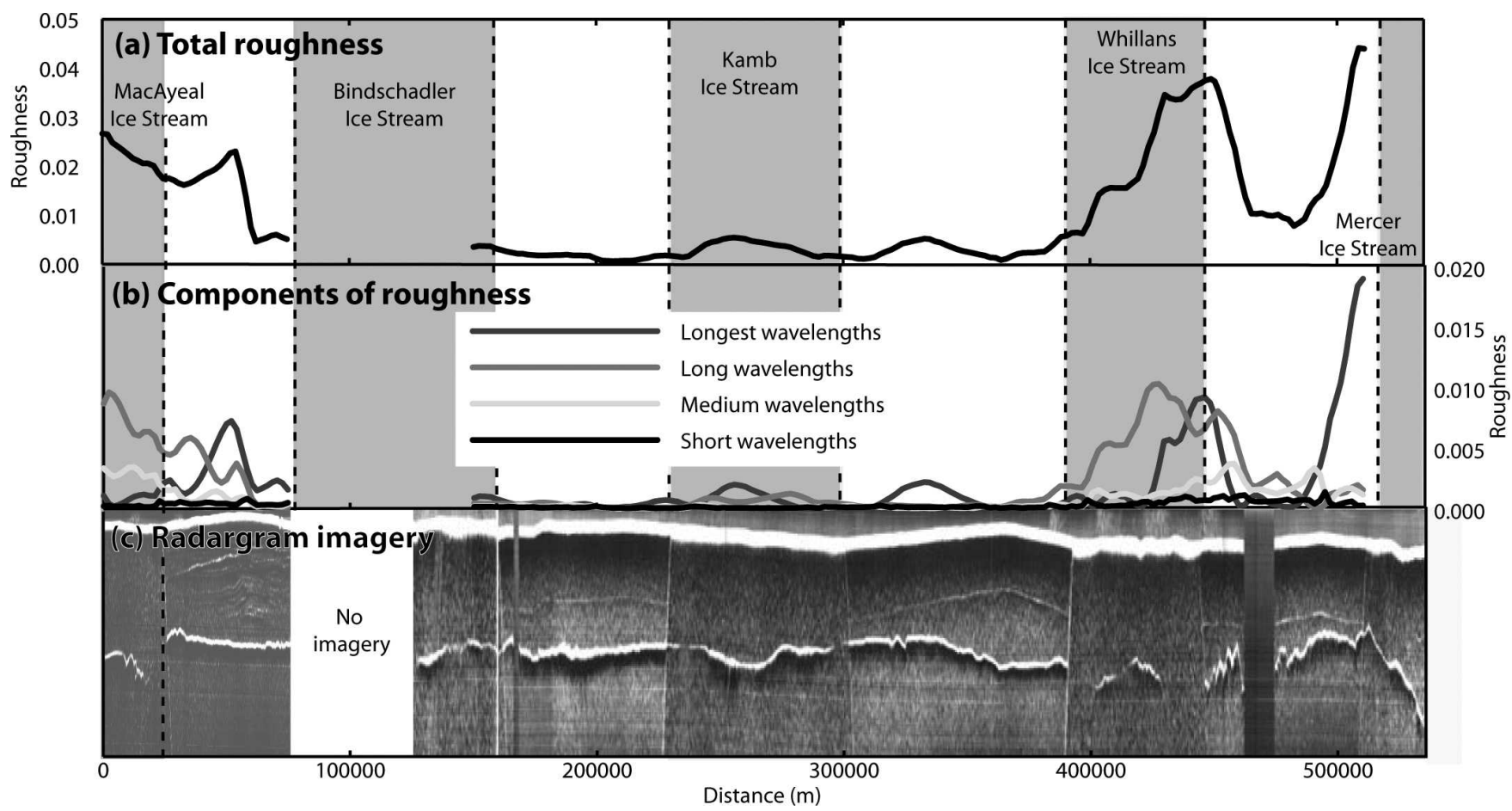

Figure 2. (a) Total roughness, (b) wavelength components of roughness, and (c) raw Z-scope RES data along a profile transecting five principal ice streams draining the Siple Coast region of Antarctica. In (b) wavelengths are as follows: longest >40 km; long 20-40 km; medium 10-20 km; and short 5-10 km. Adapted from Siegert et al. (2004b).

\section{Subglacial Roughness and Subglacial Geology}

Variations in the roughness and reflection coefficients of the bed reflector impart significant information for glacier geophysicists, in particular relating to rates of subglacial erosion and deposition, mapping of subglacial geology, and the detection of water at the base. We return to the last point in the following section.

A major recent development in the analysis of subglacial topography from airborne RES has been the quantitative regional characterisation of subglacial roughness, the wavelength-related variation of subglacial bedrock elevation with horizontal distance (Hubbard and Hubbard, 1998; Hubbard et al., 2000; Taylor et al., 2004). Bed roughness represents an important first-order measurement for understanding the potential effects of the bed in determining variations in ice dynamics over scales $>10^{2} \mathrm{~km}$. This is because: (i) a bed that is smoother, and/or softer, than in surrounding areas may promote faster ice flow by proffering less frictional resistance to ice flow; and (ii) faster ice flow may, in turn, facilitate greater erosion at the base and therefore further smoothening of subglacial topography.

Such considerations have motivated analyses of subglacial roughness beneath both the WAIS and the EAIS. Beneath the Siple Coast region of West Antarctica, Siegert et al. (2004b) found that ice streams are generally associated with low bed roughness values while intervening ridges are generally underlain by rough basal topography. This has been taken to imply a subglacial topographic control on ice stream positions, while smooth subglacial topography beneath the ice streams is consistent with their being underlain by a thick layer of deforming subglacial sediments. An exception is provided by Kamb Ice Stream (formerly Ice Stream C), whose flanking ice ridges are also underlain by remarkably smooth subglacial topography which could facilitate (and/or reflect) lateral migration of that ice stream (Fig. 2). Subglacial roughness has also been

Vostok; WLK = Wilkes Land. The area labelled ICECAP has been endorsed as a new region for surveying during the International Polar Year, 2007-09. (b) Overview of RES coverage across Arctic ice sheets and ice caps. SZ = Severnaya Zemlya; NZ = Novaya Zemlya; FJ = Franz Josef Land; SV = Svalbard. (c) Inset of Greenland RES coverage (black lines), after Bamber et al. (2003). (d) Inset showing locations of Canadian Arctic ice caps surveyed by RES. DIC = Devon Ice Cap; MIC = Manson Ice Cap; PWI = Prince of Wales Icefield; AIC = Agassiz Ice Cap. 


\section{Journal of Environmental and Engineering Geophysics}

analysed over East Antarctica, showing that whilst the ice divides at Ridge B and Dome A are underlain by rough basal topography, the subglacial interface beneath Dome $\mathrm{C}$ is surprisingly smooth. An explanation proposed for this apparent anomaly is that the subglacial morphology beneath Dome $\mathrm{C}$ is likely to predate the present ice-sheet configuration, and probably reflects substantial erosion under warm-based conditions (Siegert et al., 2005b).

Analyses of subglacial roughness therefore provide valuable insights concerning rates of subglacial erosion and/or deposition and geology (which we discuss shortly), and there is much potential for further roughness analyses using already available datasets. In Antarctica, for example, attempts to discern the influence of subglacial topography on the flow of the ice streams draining into the Filchner-Ronne Ice Shelf could benefit significantly from an analysis of subglacial roughness; and airborne RES data have already been collected over many of these ice streams (Siegert, 1999; Rippin et al., 2003a; Rippin et al., 2004). Throughout Greenland, the extensive surveys of the University of Kansas PARCA consortium (Gogineni et al., 2001) have provided the data which would facilitate widespread determination of subglacial roughness beneath the Greenland Ice Sheet. Airborne RES surveys over the Canadian and Eurasian Arctic ice caps (Dowdeswell et al., 1984, 1999, 2002, 2004) also provide the wide-ranging data required to investigate subglacial roughness, but as yet such analyses have not yet been conducted.

Airborne RES, in combination with additional aeromagnetic surveying, also constitutes one of the principal methods used to map subglacial geology beneath the major ice sheets. This is especially the case over Antarctica, where options to view the bedrock directly, via subaerial outcrops or using coring methods, are scarce. Typically, variations in subglacial roughness, the bed reflection coefficient, and the distribution of aeromagnetic anomalies are all used in combination to characterise variations in subglacial geology. Notable early studies to use these methods included Drewry's (1976) geological division of the Aurora and Wilkes basins, East Antarctica; and characterisation of the subglacial West Antarctic Rift system by Behrendt et al. (1980) and Jankowski and Drewry (1981). The use of RES methods to map subglacial geology has snowballed since the $1990 \mathrm{~s}$ as a series of targeted airborne programmes has simultaneously imaged the bed and collected gravity measurements over several key regions of Antarctica. Such surveys have exposed, for example, widespread, thick, unconsolidated sediments beneath a number of ice streams, interpreted as a vital control on their initiation and dynamics (Bell et al., 1998; Blankenship et al., 2001; Studinger et al., 2001; Bamber et al.,
2006); and the presence of an active rift system beneath the West Antarctic Ice Sheet (Blankenship et al., 1993; Behrendt, 1999, and references therein).

\section{Subglacial Water and Subglacial Lakes}

A particularly significant property of variations in RES bed echoes over polar ice masses is their use to infer whether water is present at the base, either overlying or within subglacial sediments. Significant early work in this regard was reported by Shabtaie et al. (1987), who examined airborne RES data collected over the Mercer, Whillans and Kamb Ice Streams (formerly Ice Streams A-C) and argued that relative reflection strengths (after correction for variations in subglacial geology and ice thickness) varied inversely with freezing at the bed. Bentley et al. (1998) developed this scheme further, arguing that high bed reflection strengths beneath Kamb Ice Stream evinced the existence of liquid water at its base, while low relative reflection strengths under Engelhardt Ice Ridge (Ridge BC) were taken to evidence underlying frozen till.

Ground-based RES techniques have also been developed to infer whether liquid water is present at the subglacial interface beneath polar ice. Notably, Gades (1998) developed a range of bed reflection powers (BRP) for subglacial materials ranging from frozen permafrost to a film of liquid water, and applied this categorisation to the subglacial interface from a RES profile transecting Siple Dome (Gades et al., 2000). The study highlighted that while the dome itself is underlain by frozen material, the dormant ice streams flanking the dome appear to be underlain by water-saturated material. This was interpreted as suggesting that the presence of liquid water at the basal interface alone does not enable active streaming to take place (Gades et al., 2000); rather additional conditions conducive to basal flow (e.g., weak subglacial sediments, ice stream piracy) must apply to activate streaming. The BRP method for detecting subglacial water was further extended by Catania et al. (2003), who calibrated additional RESderived measures of BRP with observations of water content in nearby boreholes. This calibration enabled Catania et al. (2003) to classify regions of low basal reflectivity as frozen at the bed, regions of high basal reflectivity as wet-based, and regions of intermediate reflectivity as a mix of the two. Applying this scheme to several further ground-based RES surveys across the Siple Coast region, Catania et al. (2003) confirmed the earlier contention of Bentley et al. (1998) that ice streams (both active and dormant) are predominantly wet-based, while the intervening ridges are frozen to the bed. Most recently, these findings have been supported by Peters et al. (2005), who developed a similar subglacial reflector classification scheme and applied it to 
Bingham and Siegert: Radio-Echo Sounding Over Polar Ice Masses
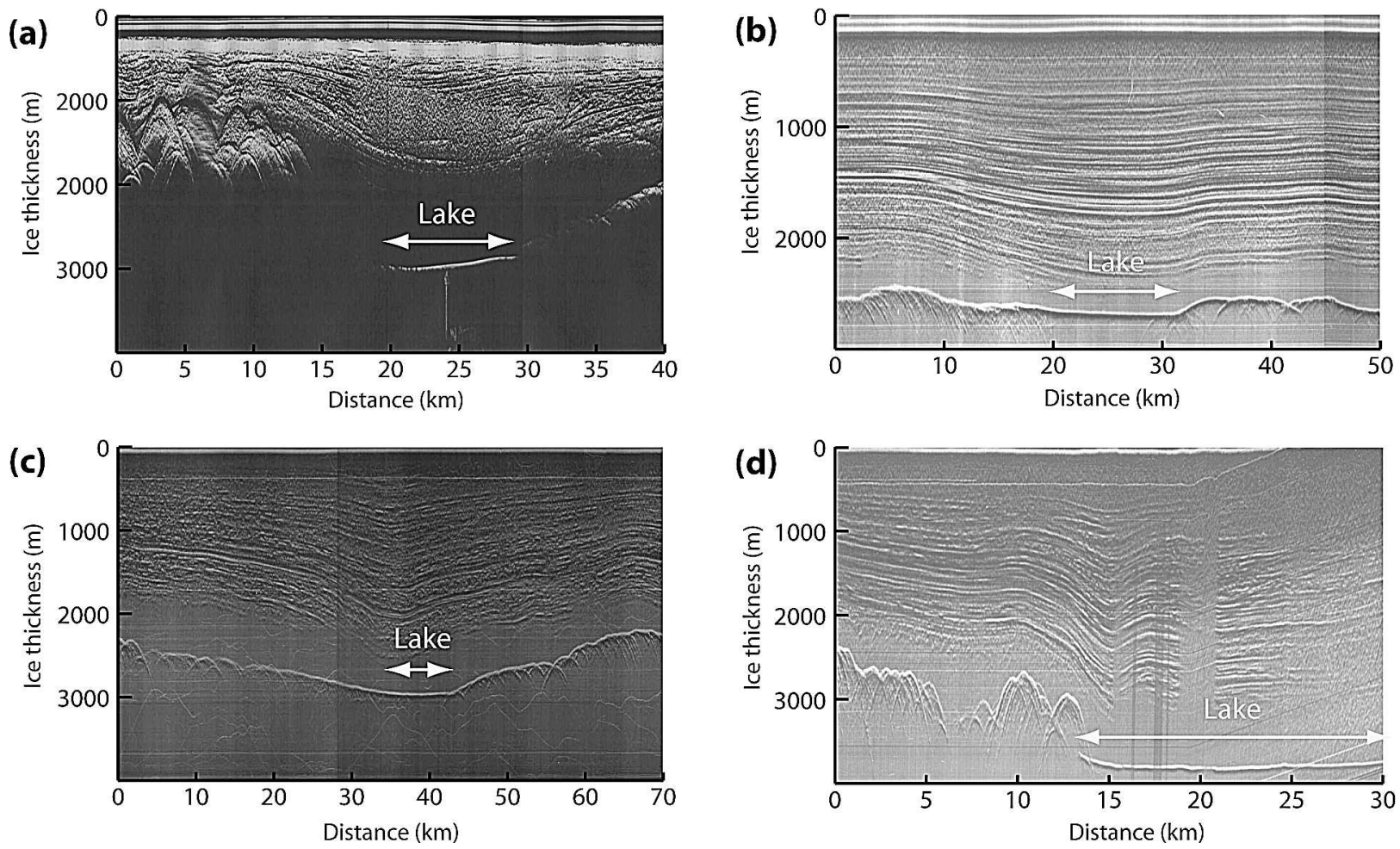

Figure 3. Examples of subglacial lakes identified from RES data collected during the SPRI-NSF-TUD campaigns 197479, and listed in Siegert et al. (2005a). (a) Lake no. 70, "Subglacial Lake Ellsworth," West Antarctica, (b) Lake no. 31, "Subglacial Lake Aurora," close to Dome C, East Antarctica, (c) Lake no. 16, in the Adventure Trench, East Antarctica, and (d) Lake. No. 2, "Lake Vostok," Antarctica's largest known subglacial lake, which continues off the right of the window imaged here.

investigate comprehensive airborne RES survey data collected over a large proportion of the Siple Coast region.

Where sufficient water is generated at the base of an ice sheet, it gathers into depressions in hydraulic potential, forming distinct bodies of subglacial water commonly termed 'subglacial lakes'. The existence of subglacial lakes, and the utility of airborne RES records in identifying them, was first discovered by observations of unusually strong and flat basal reflectors present within the SPRI-NSF-TUD airborne RES records collected across the Antarctic Ice Sheet in the late 1960s (Robin et al., 1970, 1977). Subsequently, analysing all airborne RES records collected in Antarctica up until 1971/2, Oswald and Robin (1973) inventoried 17 subglacial lakes beneath the East Antarctic Ice Sheet, identifying such features wherever: (i) bed echoes were strong, bright and typically 10-20 dB greater in strength than surrounding bed echoes; (ii) bed echoes had constant strength along track, indicating a surface that is smooth with respect to the $60 \mathrm{MHz}$ system wavelength; and (iii) bed echoes were especially flat compared with surrounding topography. The bed topography was also observed to have a reverse slope around 10 times that of the ice surface slope, consistent with a water body in hydrostatic equilibrium. 'Subglacial-lake' reflectors are therefore readily discernible from airborne RES data (e.g., Fig. 3), and the above criteria have been used to compile and update catalogues of subglacial lake locations and dimensions beneath the Antarctic Ice Sheet as new surveys have been conducted (Siegert et al., 1996; Siegert et al., 2005a).

Investigations of Antarctic subglacial lakes using airborne RES techniques have been further boosted by the discovery, initially from the SPRI-NSF-TUD records (Fig. 3d), of the vast subglacial Lake Vostok beneath East Antarctica (Oswald and Robin, 1973; Kapitsa et al., 1996). This lake fills a 230-km trough up to a depth of $1 \mathrm{~km}$, has a surface area of $\sim 14,000 \mathrm{~km}^{2}$, and has an estimated maximum water-storage volume of $>5,000 \mathrm{~km}^{3}$ (Siegert, 2005). The suggestion that it may harbour unique forms of bacterial life and/or compounds isolated by ice cover $10^{5}-10^{6}$ million yr ago, and which may therefore be analogous to extraterrestrial phenomena, has precipitated a range of efforts to drill through the ice and into this, and other, subglacial lakes in order to collect water and sediment samples for scientific analyses (Priscu et al., 2003; Siegert et al., 


\section{Journal of Environmental and Engineering Geophysics}

2004a; Inman, 2005; Tikku et al., 2005). Such investigations have been aided considerably by the use of airborne RES in constraining more accurately subglacial lake morphology in order to inform modelling investigations and to provide detailed information for future drilling projects (Tabacco et al., 2002; Studinger et al., 2004b; Cafarella et al., 2006).

The latest airborne-RES-derived inventory of Antarctic subglacial lakes, informed by the entire SPRI-NSF-TUD dataset and airborne surveys conducted over East Antarctica by Italian, Russian, and U.S. teams, now lists 145 lake-type reflectors beneath the ice sheet (Siegert et al., 2005a). Cumulatively these are estimated to contain between $4,000-12,000 \mathrm{~km}^{3}$ of water, which equates to a potential rise in global sea level of 10-35 mm. Individually, these 'lakes' probably lie along a continuum from the vast liquid body of Lake Vostok to substantial masses of water-saturated sediments.

It has recently been argued that a number of subglacial lakes, rather than being isolated, may in fact be interconnected, facilitating drainage from up-gradient to down-gradient locations, and ultimately to the ice-sheet margin (Dowdeswell and Siegert, 2003; Wingham et al., 2006). If and/or where such connected drainage does take place, it is likely to occur as a series of rapid drainage events between basins, potentially accounting for observations of rare floods (Goodwin, 1988) and spectacular water-carved landforms (e.g., Sawagaki and Hirakawa, 1997; Denton and Sugden, 2005; Margerison et al., 2005) at the margins of the ice sheet. At present, however, there remain insufficient airborne RES data over many regions of Antarctica to state definitively whether the majority of subglacial lakes are connected.

In stark contrast to the Antarctic Ice Sheet, to date no distinctive subglacial lake reflectors have been observed from RES data collected across the Greenland Ice Sheet nor the polar ice caps of the Canadian and Eurasian High Arctic.

\section{Detection and Application of Englacial Layers}

Englacial, or internal, layers (a.k.a. Internal Reflecting Horizons, IRHs) - weakly-reflecting englacial horizons that commonly extend for several $10 \mathrm{~s}$ (and sometimes $100 \mathrm{~s}$ ) of $\mathrm{km}$ across ice sheets (e.g., Fig. 4) were first identified as a fortuitous by-product of the extensive airborne RES programmes conducted over the Antarctic and Greenland Ice Sheets in the 1960s (Bailey et al., 1964). Such layers represent echoes off any boundary where there is a contrast in the dielectric properties of the ice, resulting, variously, from contrasts in ice density, electrical conductivity, and/or ice crystal fabrics. Near the surface, density variations, exemplified by contrasts between firn and occasional ice lenses, probably account for most internal reflections (Moore, 1988). Below $1 \mathrm{~km}$ of ice, however, where compression negates density contrasts, most internal layers probably manifest variations in conductivity, resulting from fluctuations in the acidity of volcanically-derived aerosols incorporated into the ice when it was first laid down during discrete snow deposition events (Millar, 1981; Paren, 1981; Hempel et al., 2000). In very deep ice $(>3 \mathrm{~km})$, subject to very large englacial stresses, changes in ice permittivity, related to the development of anisotropic or preferred crystal fabric orientations, may also be discernible as discrete internal layers (Harrison, 1973; Fujita et al., 1999; Matsuoka et al., 2003). Regardless of their origins, most internal layers picked out on RES radargrams are thought to represent constructive interference formed by radiowave reflections off several parallel and closely-spaced layers; thus the apparent thickness of individual layers observed in RES data is a function not only of its physical origins, but also the radiowave pulse length and frequencies used (Siegert, 1999; Miners et al., 2002).

Internal layers have two significant attributes which make their detection and analysis invaluable. Firstly, they most likely represent discrete, or very closely-spaced, past deposits of snow, subsequently buried by firn compaction and converted to ice layers. Internal layers may therefore be treated as isochrones; palaeosurfaces of similar age. Secondly, and following on from this, the stratigraphy of internal layers, or isochrones, results from a combination of their burial rate (or surface accumulation) and the internal flow field. These considerations have precipitated the extensive use of internal layers in analysing a broad array of glacial geophysical problems.

\section{Mass Balance}

Cross-referencing internal layers with ice cores has gained considerable currency owing to the potential for extrapolating the one-dimensional climate records held in cores to two and three dimensions. Wherever an internal layer intersects an ice core, it is possible to assign to that layer an age based on the core record (Siegert et al., 1998b; Hempel et al., 2000; Baldwin et al., 2003). This yields a spatially extensive stratigraphic control for calculations of surface accumulation along the entire length of the internal horizon being used (Nereson et al., 2000; Morse et al., 2002; Siegert and Payne, 2004). Occasionally, continuous internal layers have been traced between two or more ice cores; in which case not only do they provide a powerful means of synchronising ice core records, but they can also be used to determine accumulation rates, and their spatial 
Bingham and Siegert: Radio-Echo Sounding Over Polar Ice Masses
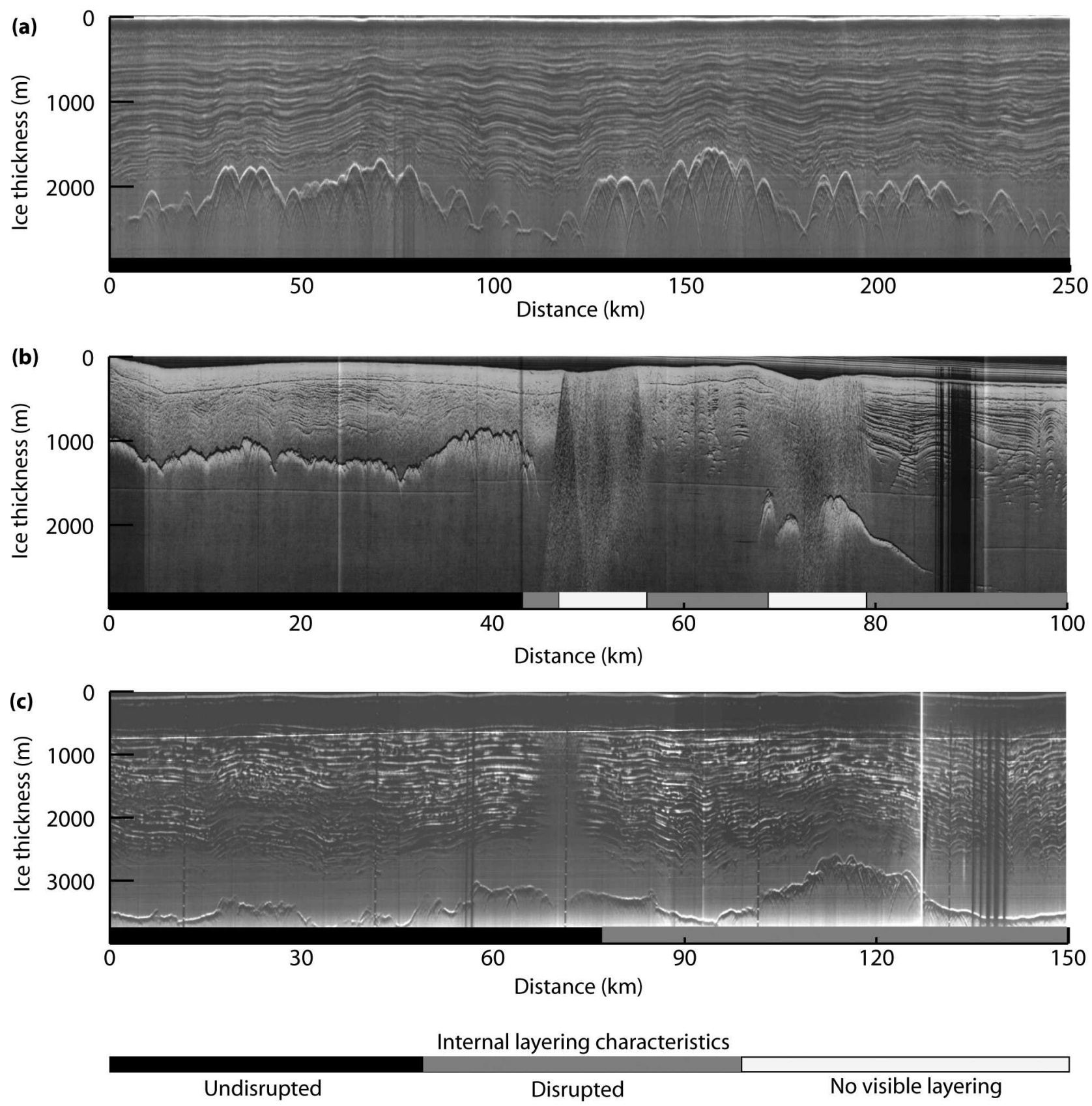

Figure 4. (a)-(c) Examples of internal layers imaged in Antarctica RES data collected during the SPRI-NSF-TUD campaigns of the 1970s, showing distinctive classes of internal layering, i.e., continuous, buckled and absent, as discussed in text.

and temporal variability, between the separate core locations (Dahl-Jensen et al., 1997; Hvidberg et al., 1997; Siegert et al., 1998a, 1998b). Within this context, continuous internal layers resolved from airborne RES surveys have proved particularly valuable, as surveys yielding unbroken records of internal horizons have been conducted over distances of several $100 \mathrm{~km}$.

Furthermore, it is now standard practice, when exploring a putative ice-coring site, to conduct RES surveys over the area in a closely-spaced grid (Steinhage et al., 2001; Morse et al., 2002; Bianchi et al., 2003; Frezzotti et al., 2004; Jacobel et al., 2005). This is driven by the requirement to select a site where the internal stratigraphy of the ice remains as undisturbed by flow as possible; thus the frequencies deployed are often designed as much to resolve internal layers as they are to image the bed. For example, detailed airborne RES surveys over the EPICA Dome $\mathrm{C}$ site have been used to 


\section{Journal of Environmental and Engineering Geophysics}

derive several regional palaeosurfaces from internal horizons, providing particularly detailed, and temporally constrained, information for the derivation of regional variations in surface accumulation across the Dome C region (Siegert et al., 2001).

In addition to calculating mass gain at the surface through accumulation, internal layers can also be used to determine mass loss at the base through melting (Fahnestock et al., 2001a; Dahl-Jensen et al., 2003). Any calculation of ice-sheet mass balance utilising internal layers as calibration must, however, account for the possible influences of vertical compression with depth, and also the potential impacts of ice flow, on internal layer stratigraphy. Beneath many ice divides, where most deep-ice cores are situated, vertical compression is stronger than elsewhere, but layer stratigraphy is typically least disturbed by lateral ice flow, thus a depth-age chronology is relatively simple to derive (Fahnestock et al., 2001b). However, deep beneath some divides ice is so slow-flowing and stiff that upper layers tend to become draped over it, leading to an apparent upwarping of internal layers around it (Raymond, 1983). Such 'Raymond Bump' phenomena may disrupt simple layer stratigraphy and complicate the derivation of depth-age relationships. Furthermore, if the divide has migrated over time, the vertical axis of the Raymond Bump may become skewed in the direction of the divide shift, further complicating depth-age relationships (Raymond, 1983; Vaughan et al., 1999; Pettit et al., 2003; Martin et al., 2006). With increasing distance away from ice divides, lateral ice flow imparts increasing disruption to internal layer stratigraphy, and the derivation of depth-age relationships becomes reliant upon relatively sophisticated ice-flow modelling (Hvidberg et al., 1997; Mayer and Siegert, 2000).

Internal layer stratigraphy thus often reflects rates of surface accumulation and basal melting, but vertical compression and three-dimensional ice flow must be incorporated into mass-balance models which use internal layers as calibration.

\section{Ice Dynamics and Ice Sheet Evolution}

Although internal layers are often more or less bed-parallel and spatially continuous over distances of several $100 \mathrm{~km}$, in some regions layer orientations diverge significantly from the bed and/or surface, and layers may become broken or indistinct. Various terms have been used to describe such disruption to englacial stratigraphy (e.g., warping, folding, buckling, distortion), but it is generally agreed that, where accumulation and melting are relatively uniform, any disruption to bed-parallel internal layering must result predominantly from ice flow. In particular, it has been observed that internal layers experience severe disruption across ice- stream margins, which may be attributed to past and present variations in the internal strain field across strain boundaries (Jacobel et al., 1993; Jacobel et al., 1996; Bell et al., 1998; Siegert et al., 2003). In the particularly well-imaged Siple Coast region of West Antarctica, disruption of internal layering demonstrably originates upstream from regions of streaming flow, and the resultant folds advect into the ice streams, where the degree of distortion may be used to constrain the accumulated shear strain since they were produced (Jacobel and Bindschadler, 1993; $\mathrm{Ng}$ and Conway, 2004). Downstream, significant flow-induced disruption to internal layers may, in extreme cases, extinguish internal layers completely (Jacobel et al., 1993). Disrupted internal layering is also widely observed across and within ice stream tributaries (Rippin et al., 2003b; Siegert et al., 2003), suggesting that wherever there is a contrast in flow conditions and strain, perhaps as a consequence of changes in basal boundary conditions at the onset of streaming, significant disruption to internal layers can occur.

The above considerations have expedited the application of airborne-RES-derived internal layers to analysing ice flow across the major ice sheets. In particular, RES data can supplement measurements of ice flow gained by satellite remote sensing methods in two ways. Firstly, whereas satellites can perceive only surface flow variations, internal layers provide timetransgressive records of past variations in ice flow extending deep beneath the surface. Secondly, in a number of regions where satellite constraints on ice flow are currently lacking, internal layers provide the only empirical evidence for variations in ice flow across wide expanses of ice sheets. Thus, several studies (Rippin et al., 2003b; Siegert et al., 2003; Bingham et al., in press) have divided the Antarctic Ice Sheet into distinct regions in which internal layers are either: (i) continuous/undisrupted, in that they are easily identifiable and relatively flat over large distances; or (ii) buckled/disrupted, i.e., internal layers diverge significantly from the wavelengths of the underlying subglacial topography (e.g., Fig. 4). Regions in which internal layers are absent are generally excluded from this type of analysis as it is often difficult to determine whether layers genuinely do not exist or the RES equipment has failed to capture them.

In applying this classification scheme to extensive airborne RES data, Siegert et al. (2003) showed that the margins and tributaries of Bindschadler Ice Stream (formerly Ice Stream D) were characterised by disrupted internal layering, whilst layering in the ridges to each side stayed largely undisrupted. That this remained true deep beneath the ice surface was taken as an indication that this ice stream and its tributaries have not migrated 
Bingham and Siegert: Radio-Echo Sounding Over Polar Ice Masses

recently - in stark contrast to the neighbouring Kamb Ice Stream, which is thought to have experienced several switches in its configuration, evidenced by disrupted internal layering within both it and its current bounding ridges (Catania et al., 2006). Examining airborne RES records over the much larger region of Wilkes Land, East Antarctica, Rippin et al. (2003b) further confirmed that disrupted internal layering is widely diagnostic of ice-flow tributaries as identified from interferometric synthetic aperture radar (InSAR). Therefore, regions of disrupted internal layering may be used to identify past and present ice streams and tributaries where no satellite-derived measurements of surface ice flow are available. This is particularly so in central East Antarctica, south of $86^{\circ} \mathrm{S}$, the current latitudinal limit of ICESat, where Bingham et al. (in press) used disrupted internal layers to remap the distribution of tributaries around the South Pole, thereby providing an empirical constraint to previous ice flow distributions yielded by balance-flux modelling (Bamber et al., 2000; $\mathrm{Wu}$ and Jezek, 2004). In all studies using disruption to internal layers as an indicator of fast or tributary flow, however, it is important also to account for possible disruptions to internal layering caused by other factors, such as variations in subglacial topography, accumulation and melt rates, for example. Only by reasonably discounting these non-flow induced causes of layer disruption can internal layering variations truly be attributed to variations in ice flow alone.

Internal layers, and their three-dimensional architecture, therefore offer myriad information concerning mass balance and ice flow properties over vast spatial extents of the polar ice sheets and ice caps; information which could not be gathered with such ease by any other means. However, to date, the analysis of these growing datasets has remained largely restricted to two dimensions. As additional airborne RES datasets are gathered, especially from previously unexplored sectors of the polar ice sheets and ice caps, and our capacity to view the interior of the ice sheet in three dimensions consequently grows, the challenge lying ahead will be to develop increasingly sophisticated methods for visualising and interpreting internal layers and threedimensional palaeosurfaces in line with developments in the three-dimensional modelling of ice sheet evolution.

\section{Summary and Future Recommendations for Airborne RES}

RES provides a powerful, non-invasive and wideranging means of imaging the subsurface properties of ice sheets and ice caps. It can be operated from both airborne and ground-based (over-snow) platformsalthough both essentially measure the same properties, airborne surveys offer the easiest means of obtaining wide, regional-scale coverages, and have therefore predominated over ice sheets and ice caps, while ground-based surveys can provide finer detail and afford greater control in areas of more complex topography and may be used simply where aircraft are unavailable. Originally developed as a method for locating and mapping the subglacial interface over extensive regions of ice-covered terrain, thereby to calculate the total volume of ice on the Earth, it was quickly discovered that RES offers a great deal of further information concerning englacial and subglacial environments, including the ability to identify subglacial lakes and to resolve isochronous internal reflectors. Thus, four decades since major airborne RES programmes were initiated over Antarctica and Greenland, numerous campaigns have sought to:

(i) map subglacial topography beneath the Earth's ice sheets and ice caps at an ever-increasing resolution;

(ii) characterise bed returns in terms of subglacial roughness, bed geology and the presence or absence of liquid water;

(iii) constrain the locations and geometry of subglacial lakes; and

(iv) resolve englacial stratigraphy, for a variety of purposes including siting deep-ice cores, constraining mass balance (surface accumulation and basal melting) over spatially extensive regions; and analysing three-dimensional ice flow through comparison with existing internal layer architecture.

The datasets gathered, and the increasingly sophisticated, complex and high-resolution numerical models into which these data are being incorporated, have yielded significant advances in our knowledge of cryosphere/climate/sea-level interactions across the high latitudes, demonstrating the incomparable value of RES to glacial geophysical research. Yet many polar icecovered areas remain unexplored, many have not been revisited since significant improvements in data acquisition and processing have been made, and many existing datasets have not been analysed fully in line with theoretical advances in the interpretation and applications of RES data. Thus, in terms of future developments in the acquisition and analysis of airborne RES data over the polar ice sheets and ice caps, we make the following recommendations:

(i) Subglacial topography must be surveyed over icecovered terrain which, to date, has not been imaged. For example, there remain significant gaps in the RES coverage of Antarctica over which, consequently, we have no knowledge of subglacial topography nor englacial stratigraphy. In particular, subglacial topography beneath the interior of 


\section{Journal of Environmental and Engineering Geophysics}

much of the East Antarctic Ice Sheet has never been measured, severely hampering efforts to model the response of this 12.4 million $\mathrm{km}^{2}$ ice mass to climate change. To conduct these surveys will require RES equipment to be mounted on long-range aircraft for the first time since the SPRINSF-TUD surveys were discontinued in 1979. Over Greenland, while much of the ice sheet has been comprehensively surveyed by the PARCA programme, subglacial topography has still not been adequately surveyed beneath the major ice streams, hindering attempts to model the future of this ice sheet. This is largely due to inadequate penetration of the RES signal through the ice where scattering is dominant and the ice is thick and warm, and to overcome this problem will require both the construction of new radar equipment with greater power and more focus, and new processing algorithms capable of accounting for scattering and strong attenuation. Elsewhere, examples of significant unsurveyed ice caps include North Ice Cap, Novaya Zemlya $\left(23,600 \mathrm{~km}^{2}\right)$, and the ice caps of Canada's Ellesmere $\left(80,500 \mathrm{~km}^{2}\right)$ and Axel Heiberg Islands $\left(11,700 \mathrm{~km}^{2}\right)$. RES surveys of all these regions/ice caps can provide the information that is necessary for an accurate assessment of their potential responses to climate change.

(ii) As gaps in the existing coverage continue to be filled incrementally, and airborne RES acquisition and processing techniques continue to be refined, a shift in emphasis should take place from RES programs directed predominantly towards surveying the basal reflector in unexplored regions to campaigns targeted towards investigating specific 'ice sheet evolution' hypotheses through the coordinated gathering of data on both the basal interface and internal layers. Because numerical models increasingly require higher resolution data both on basal topography and englacial layering, and because we are now able to image the bed beneath deeper ice and resolve more internal layers than ever before, this should involve resurveying key regions of the polar ice sheets and ice caps at a higher resolution than has previously been achieved.

(iii) In line with the acquisition of new RES data and concurrent advances in remote sensing and numerical modelling techniques, significant efforts need to be made to coordinate and combine existing datasets, and to improve their three-dimensional visualisation and incorporation into glaciological models. Such developments will lead to significant new insights into the critical role that land ice plays in responding to climate change and contributing to changes in sea level.

\section{Acknowledgments}

Funding for work associated with this review was provided by the U.K. Natural Environment Council Centre for Polar Observation and Modelling (NERC-CPOM). We thank the reviewers, Ginny Catania and Robert Jacobel, and the associate editor John Woodward, for comments which helped to improve the manuscript considerably.

\section{References}

Arthern, R.J., and Hindmarsh, R.C.A., 2003, Optimal estimation of changes in the mass of ice sheets: Journal of Geophysical Research, 108, Art. No. F16007.

Bailey, J.T., Evans, S., and Robin, G.de Q., 1964, Radio-echo sounding of polar ice sheets: Nature, 204, 420-421.

Baldwin, D.J., Bamber, J.L., Payne, A.J., and Layberry, R.L., 2003, Using internal layers from the Greenland ice sheet, identified from radio-echo sounding data, with numerical models: Annals of Glaciology, 37, 325-330.

Bamber, J.L., Baldwin, D.J., and Gogineni, S.P., 2003, A new bedrock and surface elevation dataset for modelling the Greenland ice sheet: Annals of Glaciology, 37, 351-356.

Bamber, J.L., Ferraccioli, F., Joughin, I., Shepherd, T., Rippin, D.M., Siegert, M.J., and Vaughan, D.G., 2006, East Antarctic ice stream tributary underlain by major sedimentary basin: Geology, 34, 33-36.

Bamber, J.L., Layberry, R.L., and Gogineni, S., 2001, A new ice thickness and bed data set for the Greenland ice sheet 1. Measurement, data reduction, and errors: Journal of Geophysical Research, 106, 33773-33780.

Bamber, J.L., Vaughan, D.G., and Joughin, I., 2000, Widespread complex flow in the interior of the Antarctic ice sheet: Science, 287, 1248-1250.

Behrendt, J.C., 1999, Crustal and lithospheric structure of the West Antarctic Rift System from geophysical investigations - a review: Global and Planetary Change, 23, $25-44$.

Behrendt, J.C., Drewry, D.J., Jankowski, E., and Grim, M.S., 1980, Aeromagnetic and radio echo ice-sounding measurements show much greater area of the Dufek intrusion: Science, 209, 1014-1017.

Bell, R.E., Blankenship, D.D., Finn, C.A., Morse, D.L., Scambos, T.A., Brozena, J.M., and Hodge, S.M., 1998, Influence of subglacial geology on the onset of a West Antarctic ice stream from aerogeophysical observations: Nature, 394, 58-62.

Bentley, C.R., Lord, N., and Liu, C., 1998, Radar reflections reveal a wet bed beneath stagnant Ice Stream $\mathrm{C}$ and a frozen bed beneath ridge $\mathrm{BC}$, West Antarctica: Journal of Glaciology, 44, 149-156.

Bianchi, C., Cafarella, L., De Michelis, P., Forieri, A., Frezzotti, M., Tabacco, I.E., and Zirizzotti, A., 2003, Radio Echo Sounding (RES) investigations at Talos Dome (East Antarctica): bedrock topography and ice thickness: Annals of Geophysics, 46, 1265-1270.

Bindschadler, R., 1998, Monitoring ice sheet behavior from space: Reviews of Geophysics, 36, 79-104. 


\section{Bingham and Siegert: Radio-Echo Sounding Over Polar Ice Masses}

Bingham, R.G., Siegert, M.J., Young, D.A., and Blankenship, D.D., in press, Organised flow from the South Pole to the Filchner-Ronne Ice Shelf: an assessment of balance velocities in interior East Antarctica using radio-echo sounding data: Journal of Geophysical Research, accepted November 2006.

Björnsson, H., Gjessing, Y., Hamran, S.E., Hagen, J.O., Liestol, O., Palsson, F., and Erlingsson, B., 1996, The thermal regime of sub-polar glaciers mapped by multifrequency radio-echo sounding: Journal of Glaciology, 42, 23-32.

Blankenship, D.D., Bell, R.E., Hodge, S.M., Brozena, J.M., Behrendt, J.C., and Finn, C.A., 1993, Active volcanism beneath the West Antarctic Ice-Sheet and implications for ice-sheet stability: Nature, 361, 526-529.

Blankenship, D.D., Morse, D.L., Finn, C.A., Bell, R.E., Peters, M.E., Kempf, S.D., Hodge, S.M., Studinger, M., Behrendt, J.C., and Brozena, J.M., 2001, Geological controls on the initiation of rapid basal motion for West Antarctic ice streams: a geophysical perspective including new airborne radar sounding and laser altimetry results: in The West Antarctic Ice Sheet: Behavior and Environment, Alley, R.B., and Bindschadler, R.A. (eds.), American Geophysical Union, Washington, D.C., 105-121.

Bogorodskiy, V.V., Bentley, C.R., and Gudmandsen, P., 1985. Radioglaciology: Kluwer, Dordrecht.

Braaten, D., Gogineni, S.P., Tammana, D., Namburi, S., Paden, J., and Gurumoorthy, K.K., 2002, Improvement of radar ice-thickness measurements of Greenland outlet glaciers using SAR processing: Annals of Glaciology, 35, 73-78.

Cafarella, L., Urbini, S., Bianchi, C., Zirizzotti, A., Tabacco, I.E., and Forieri, A., 2006, Five subglacial lakes and one of Antarctica's thickest ice covers newly determined by radio echo sounding over the Vostok-Dome $\mathrm{C}$ region: Polar Research, 25, 69-73.

Catania, G.A., Conway, H.B., Gades, A.M., Raymond, C.F., and Engelhardt, H., 2003, Bed reflectivity beneath inactive ice streams in West Antarctica: Annals of Glaciology, 36, 287-291.

Catania, G.A., Scambos, T.A., Conway, H., and Raymond, C.F., 2006, Sequential stagnation of Kamb Ice Stream, West Antarctica: Geophysical Research Letters, 33, Art. No. L14502.

Dahl-Jensen, D., Gundestrup, N., Gogineni, S.P., and Miller, H., 2003, Basal melt at NorthGRIP modeled from borehole, ice-core and radio-echo sounder observations: Annals of Glaciology, 37, 207-212.

Dahl-Jensen, D., Gundestrup, N.S., Keller, K., Johnsen, S.J., Gogineni, S., Allen, C.T., Chuah, T.S., Miller, H., Kipfstuhl, S., and Waddington, E.D., 1997, A search in north Greenland for a new ice-core drill site: Journal of Glaciology, 43, 300-306.

Davis, M.B., Blankenship, D.D., and Holt, J.W., 2004, Subglacial geology of the southern Transantarctic Mountains, Antarctica, from airborne radar sounding: EOS Transactions, AGU, 85, T11A-1235.
Denton, G.E., and Sugden, D.E., 2005, Meltwater features that suggest Miocene ice-sheet overriding of the Transantarctic Mountains in Victoria Land, Antarctica: Geografiska Annaler, 87, 67-85.

Dowdeswell, J.A., Bassford, R.P., Gorman, M.R., Williams, M., Glazovsky, A.F., Macheret, Y.Y., Shepherd, A.P., Vasilenko, Y.V., Savatyuguin, L.M., Hubberten, H.W., and Miller, H., 2002, Form and flow of the Academy of Sciences Ice Cap, Severnaya Zemlya, Russian High Arctic: Journal of Geophysical Research, 107B, Art. No. 2076.

Dowdeswell, J.A., Benham, T.J., Gorman, M.R., Burgess, D., and Sharp, M.J., 2004, Form and flow of the Devon Island Ice Cap, Canadian Arctic: Journal of Geophysical Research, 109, Art. No. F02002.

Dowdeswell, J.A., Drewry, D.J., Liestol, O., and Orheim, O., 1984, Radio-echo sounding of Spitsbergen glaciers: problems in the interpretation of layer and bottom returns: Journal of Glaciology, 30, 16-21.

Dowdeswell, J.A., and Evans, S., 2004, Investigations of the form and flow of ice sheets and glaciers using radio-echo sounding: Reports on Progress in Physics, 67, 1821-1861.

Dowdeswell, J.A., Glazovsky, A.F., and Macheret, Y.Y., 1999, Ice divides and drainage basins on the ice caps of Franz Josef Land, Russian High Arctic, defined from Landsat, KFA-1,000, and ERS-1 SAR satellite imagery: Arctic and Alpine Research, 27, 264-270.

Dowdeswell, J.A., and Siegert, M.J., 2003, The physiography of modern Antarctic subglacial lakes: Global and Planetary Change, 35, 221-236.

Drewry, D.J., 1976, Sedimentary basins of the East Antarctic craton from geophysical evidence: Tectonophysics, 36, 301-314.

Drewry, D.J., 1983. Antarctica: Glaciological and Geophysical Folio: Cambridge University Press, Cambridge.

Drewry, D.J., Liestol, O., Neal, C.S., Orheim, O., and Wold, B., 1980, Airborne radio-echo sounding of glaciers in Svalbard: Polar Record, 20, 261-275.

Evans, S., and Robin, G.d.Q., 1966, Glacier depth sounding from the air: Nature, 210, 883-885.

Fahnestock, M., Abdalati, W., Joughin, I., Brozena, J., and Gogineni, P., 2001a, High geothermal heat flow, basal melt and the origin of rapid ice flow in central Greenland: Science, 294, 2338-2342.

Fahnestock, M., Abdalati, W., Luo, S., and Gogineni, S., 2001b, Internal layer tracing and age-depth-accumulation relationships for the northern Greenland ice sheet: Journal of Geophysical Research, 106, 33789-33797.

Ferraccioli, F., Jones, P.C., Curtis, M.L., and Leat, P.T., 2005, Subglacial imprints of early Gondwana break-up as identified from high resolution aerogeophysical data over western Dronning Maud Land, East Antarctica: Terra Nova, 17, 573-579.

Forieri, A., Zuccoli, L., Bini, A., Zirizzotti, A., Remy, F., and Tabacco, I.E., 2004, New bedrock map of Dome C, Antarctica, and morphostructural interpretation of the area: Annals of Glaciology, 39, 321-325. 


\section{Journal of Environmental and Engineering Geophysics}

Frezzotti, M., Bitelli, G., De Michelis, P., Deponti, A., Forieri, A., Gandolfi, S., Maggi, V., Mancini, F., Remy, F., Tabacco, I.E., Urbini, S., Vittuari, L., and Zirizzottl, A., 2004, Geophysical survey at Talos Dome, East Antarctica: the search for a new deep-drilling site, in Annals of Glaciology, 39, 423-432.

Fujita, S., Maeno, H., Uratsuka, S., Furukawa, T., Mae, S., Fujii, Y., and Watanabe, O., 1999, Nature of radio echo layering in the Antarctic ice sheet detected by a twofrequency experiment: Journal of Geophysical Research, 104, 13013-13024.

Gades, A.M., 1998, Spatial and temporal variations of basal conditions beneath glaciers and ice sheets inferred from radio echo soundings: $\mathrm{Ph} . \mathrm{D}$. thesis, University of Washington.

Gades, A.M., Raymond, C.F., Conway, H., and Jacobel, R.W., 2000, Bed properties of Siple Dome and adjacent ice streams, West Antarctica, inferred from radio-echo sounding measurements: Journal of Glaciology, 46, 88-94.

Gogineni, S., Tammana, D., Braaten, D., Leuschen, C., Akins, T., Legarsky, J., Kanagaratnam, P., Stiles, J., Allen, C., and Jezek, K., 2001, Coherent radar ice thickness measurements over the Greenland ice sheet: Journal of Geophysical Research, 106, 33761-33772.

Goodwin, I.D., 1988, The nature and origin of a jökulhlaup near Casey Station, Antarctica: Journal of Glaciology, 34, 94-101.

Gudmandsen, P., 1969, Airborne radio-echo sounding of the Greenland ice sheet: Geographical Journal, 135, 548-551.

Harrison, C., 1973, Radio echo sounding of horizontal layers in ice: Journal of Glaciology, 12, 383-397.

Hempel, L., Thyssen, F., Gundestrup, N., Clausen, H.B., and Miller, H., 2000, A comparison of radio-echo sounding data and electrical conductivity of the GRIP ice core: Journal of Glaciology, 46, 369-374.

Hodge, S.M., Wright, D.L., Bradley, J.A., Jacobel, R.W., Skou, N., and Vaughn, B., 1990, Determination of the surface and bed topography in central Greenland: Journal of Glaciology, 36, 17-30.

Holt, J.W., Blankenship, D.D., Morse, D.L., Young, D.A., Peters, M.E., Kempf, S.D., Richter, T.G., Vaughan, D.G., and Corr, H.F.J., 2006, New boundary conditions for the West Antarctic Ice Sheet: Subglacial topography of the Thwaites and Smith Glacier catchments: Geophysical Research Letters, 33, Art. No. L09502.

Hubbard, B., and Hubbard, A., 1998, Bedrock surface roughness and the distribution of subglacially precipitated carbonate deposits: Implications for formation at Glacier de Tsanfleuron, Switzerland: Earth Surface Processes and Landforms, 23, 261-270.

Hubbard, B., Siegert, M.J., and McCarroll, D., 2000, Spectral roughness of glaciated bedrock geomorphic surfaces: implications for glacier sliding: Journal of Geophysical Research, 105, 21295-21303.

Hvidberg, C.S., Dahl-Jensen, D., and Waddington, E.D., 1997, Ice flow between the Greenland Ice Core Project and Greenland Ice Sheet Project 2 boreholes in central
Greenland: Journal of Geophysical Research, 102, 26851-26859.

Inman, M., 2005, Antarctic drilling: the plan to unlock Lake Vostok: Science, 310, 611-612.

Jacobel, R.W., and Bindschadler, R., 1993, Radar studies at the mouths of Ice Streams D and E, Antarctica: Annals of Glaciology, 17, 262-268.

Jacobel, R.W., Gades, A.M., Gottschling, D.L., Hodge, S.M., and Wright, D.L., 1993, Interpretation of radar-detected internal layer folding in West Antarctic ice streams: Journal of Glaciology, 39, 528-537.

Jacobel, R.W., and Hodge, S.M., 1995, Radar internal layers from the Greenland summit: Geophysical Research Letters, 22, 587-590.

Jacobel, R.W., Scambos, T.A., Raymond, C.F., and Gades, A.M., 1996, Changes in the configuration of ice stream flow from the West Antarctic Ice Sheet: Journal of Geophysical Research, 101, 5499-5504.

Jacobel, R.W., Welch, B.C., Steig, E.J., and Schneider, D.P., 2005, Glaciological and climatic significance of Hercules Dome, Antarctica: An optimal site for deep ice core drilling: Journal of Geophysical Research, 110, Art. No. F01015.

Jankowski, E.J., and Drewry, D.J., 1981, The structure of West Antarctica from geophysical studies: Nature, 291, $17-21$.

Kapitsa, A., Ridley, J.K., Robin, G.d.Q., Siegert, M.J., and Zotikov, I., 1996, Large deep freshwater lake beneath the ice of central East Antarctica: Nature, 381, 684-686.

Létreguilly, A., Huybrechts, P., and Reeh, N., 1991, Steadystate characteristics of the Greenland ice sheet under different climates: Journal of Glaciology, 37, 149-157.

Lythe, M.B., Vaughan, D.G., and the BEDMAP consortium, 2001, BEDMAP: A new ice thickness and subglacial topographic model of Antarctica: Journal of Geophysical Research-Solid Earth, 106, 11335-11351.

Macheret, Y.Y., and Zhuravlev, A.B., 1982, Radio-echo sounding of Svalbard glaciers: Journal of Glaciology, 28, 295-314.

Margerison, H.R., Phillips, W.M., Stuart, F.M., and Sugden, D.E., 2005, Cosmogenic He-3 concentrations in ancient flood deposits from the Coombs Hills, northern Dry Valleys, East Antarctica: interpreting exposure ages and erosion rates: Earth and Planetary Science Letters, 230, 163-175.

Martin, C., Hindmarsh, R.C.A., and Navarro, F.J., 2006, Dating ice flow change near the flow divide at Roosevelt Island, Antarctica, by using a thermomechanical model to predict radar stratigraphy: Journal of Geophysical Research, 111, Art. No. F01011.

Matsuoka, K., Furukawa, T., Fujita, S., Maeno, H., Uratsuka, S., Naruse, R., and Watanabe, O., 2003, Crystal orientation fabrics within the Antarctic ice sheet revealed by a multipolarization plane and dual-frequency radar survey: Journal of Geophysical Research, 108, Art. No. 2499.

Mayer, C., and Siegert, M.J., 2000, Numerical modelling of ice-sheet dynamics across the Vostok subglacial lake, 
Bingham and Siegert: Radio-Echo Sounding Over Polar Ice Masses

central East Antarctica: Journal of Glaciology, 46, 197-205.

Mercer, J.H., 1978, West Antarctic Ice Sheet and $\mathrm{CO}_{2}$ greenhouse effect: a threat of disaster?: Nature, 271, 321-325.

Millar, D.H.M., 1981, Radio-echo layering in polar ice sheets and past volcanic activity: Nature, 292, 441-443.

Miners, W.D., Wolff, E.W., Moore, J.C., Jacobel, R., and Hempel, L., 2002, Modeling the radio echo reflections inside the ice sheet at Summit, Greenland: Journal of Geophysical Research, 107, Art. No. 2172.

Moore, J., 1988, Dielectric variability of a $130 \mathrm{~m}$ Antarctic ice core: implications for radar sounding: Annals of Glaciology, 11, 95-99.

Morse, D.L., Blankenship, D.D., Waddington, E.D., and Neumann, T.A., 2002, A site for deep ice coring in West Antarctica: results from aerogeophysical surveys and thermo-kinetic modeling: Annals of Glaciology, 35, $36-44$.

Narod, B.B., Clarke, G.K.C., and Prager, K.T., 1988, Airborne UHF radar sounding of glaciers and ice shelves, northern Ellesmere Island, Arctic Canada: Canadian Journal of Earth Sciences, 25, 95-105.

Nereson, N.A., Raymond, C.F., Jacobel, R.W., and Waddington, E.D., 2000, The accumulation pattern across Siple Dome, West Antarctica, inferred from radardetected internal layers: Journal of Glaciology, 46, 75-87.

Ng, F., and Conway, H., 2004, Fast-flow signature in the stagnated Kamb Ice Stream, West Antarctica: Geology, 32, 481-484.

O’Neil, R.A., and Jones, S.J., 1975, Radio depth sounding on Barnes Ice Cap: Journal of Glaciology, 15, 458-459.

Oswald, G.K.A., and Robin, G.d.Q., 1973, Lakes beneath the Antarctic Ice Sheet: Nature, 245, 251-254.

Paren, J., 1981, Reflection coefficient at a dielectric interface: Journal of Glaciology, 27, 203-204.

Peters, M.E., Blankenship, D.D., and Morse, D.L., 2005, Analysis techniques for coherent airborne radar sounding: Application to West Antarctic ice streams: Journal of Geophysical Research, 110, Art. No. B06303.

Pettit, E.C., Jacobson, H.P., and Waddington, E.D., 2003, Effects of basal sliding on isochrones and flow near an ice divide: Annals of Glaciology, 37, 370-376.

Plewes, L.A., and Hubbard, B., 2001, A review of the use of radio-echo sounding in glaciology: Progress in Physical Geography, 25, 203-236.

Priscu, J.C., Bell, R.E., Bulat, S.A., Ellis-Evans, J.C., and Kennicutt II, M.C., 2003, An international plan for Antarctic subglacial lake exploration: Polar Geography, 27, 69-83.

Raymond, C.F., 1983, Deformation in the vicinity of ice divides: Journal of Glaciology, 29, 357-373.

Remy, F., and Tabacco, I.E., 2000, Bedrock features and ice flow near the EPICA ice core site (Dome C, Antarctica): Geophysical Research Letters, 27, 405-408.

Retzlaff, R., Lord, N., and Bentley, C., 1993, Airborne radar studies: Ice Streams A, B and C, West Antarctica: Journal of Glaciology, 39, 495-506.
Rignot, E., and Kanagaratnam, P., 2006, Changes in the velocity structure of the Greenland Ice Sheet: Science, 311, 986-990.

Rignot, E., Thomas, R.H., Kanagaratnam, P., Casassa, G., Frederick, E., Gogineni, S., Krabill, W., Rivera, A., Russell, R., Sonntag, J., Swift, R., and Yungel, J., 2004, Improved estimation of the mass balance of glaciers draining into the Amundsen Sea sector of West Antarctica from the CECS/NASA 2002 campaign: Annals of Glaciology, 39, 231-237.

Rippin, D.M., Bamber, J.L., Siegert, M.J., Vaughan, D.G., and Corr, H.F.J., 2003a, Basal topography and ice flow in the Bailey/Slessor region of East Antarctica: Journal of Geophysical Research, 108, Art. No. F16008.

Rippin, D.M., Bamber, J.L., Siegert, M.J., Vaughan, D.G., and Corr, H.F.J., 2004, The role of ice thickness and bed properties on the dynamics of the enhanced-flow tributaries of Bailey Ice Stream and Slessor Glacier, East Antarctica: Annals of Glaciology, 39, 366-372.

Rippin, D.M., Siegert, M.J., and Bamber, J.L., 2003b, The englacial stratigraphy of Wilkes Land, East Antarctica, as revealed by internal radio-echo sounding layering, and its relationship with balance velocities: Annals of Glaciology, 36, 189-196.

Robin, G.de Q., Drewry, D.J., and Meldrum, D.T., 1977, International studies of ice sheet and bedrock: Philosophical Transactions of the Royal Society of London: B, 279, 185-196.

Robin, G.de Q., Swithinbank, C.W.M., and Smith, B.M.E., 1968, Radio echo exploration of the Antarctic ice sheet International Symposium on Antarctic Glaciological Exploration (ISAGE): Hanover, NH, USA, 3-7 September, 1968.

Sawagaki, T., and Hirakawa, K., 1997, Erosion of bedrock by subglacial meltwater, Soya Coast, East Antarctica: Geografiska Annaler, 79, 223-238.

Shabtaie, S., Whillans, I.M., and Bentley, C.R., 1987, The morphology of Ice Streams A, B, and C, West Antarctica, and their environs: Journal of Geophysical Research, 92, 8865-8883.

Siegert, M.J., 1999, On the origin, nature and uses of Antarctic ice-sheet radio-echo layering: Progress in Physical Geography, 23, 159-179.

Siegert, M.J., 2005, Lakes beneath the ice sheet: The occurrence, analysis, and future exploration of Lake Vostok and other Antarctic subglacial lakes: Annual Review of Earth and Planetary Sciences, 33, 215-245.

Siegert, M.J., Carter, S., Tabacco, I., Popov, S., and Blankenship, D.D., 2005a, A revised inventory of Antarctic subglacial lakes: Antarctic Science, 17, 453-460.

Siegert, M.J., Dowdeswell, J.A., Gorman, M.R., and McIntyre, N.F., 1996, An inventory of Antarctic sub-glacial lakes: Antarctic Science, 8, 281-286.

Siegert, M.J., Eyers, R.D., and Tabacco, I.E., 2001, Threedimensional ice sheet structure at Dome C, central East Antarctica: implications for the interpretation of the EPICA ice core: Antarctic Science, 13, 182-187.

Siegert, M.J., Hindmarsh, R., Corr, H., Smith, A., Woodward, J., King, E.C., Payne, A.J., and Joughin, I., 2004a, 


\section{Journal of Environmental and Engineering Geophysics}

Subglacial Lake Ellsworth: A candidate for in situ exploration in West Antarctica: Geophysical Research Letters, 31, Art. No. L32403.

Siegert, M.J., Hodgkins, R., and Dowdeswell, J.A., 1998a, A chronology for the Dome $\mathrm{C}$ deep ice-core site through radio-echo layer correlation with the Vostok ice core, Antarctica: Geophysical Research Letters, 25, 1019-1022.

Siegert, M.J., Hodgkins, R., and Dowdeswell, J.A., 1998b, Internal radio-echo layering at Vostok station, Antarctica, as an independent stratigraphic control on the icecore record: Annals of Glaciology, 27, 360-364.

Siegert, M.J., and Payne, A.J., 2004, Past rates of accumulation in central West Antarctica: Geophysical Research Letters, 31, Art. No. L12403.

Siegert, M.J., Payne, A.J., and Joughin, I., 2003, Spatial stability of Ice Stream D and its tributaries, West Antarctica, revealed by radio-echo sounding and interferometry: Annals of Glaciology, 37, 377-382.

Siegert, M.J., Taylor, J., and Payne, A.J., 2005b, Spectral roughness of subglacial topography and implications for former ice-sheet dynamics in East Antarctica: Global and Planetary Change, 45, 249-263.

Siegert, M.J., Taylor, J., Payne, A.J., and Hubbard, B., 2004b, Macro-scale bed roughness of the Siple Coast ice streams in West Antarctica: Earth Surface Processes and Landforms, 29, 1591-1596.

Steinhage, D., Nixdorf, U., Meyer, U., and Miller, H., 1999, New maps of the ice thickness and subglacial topography in Dronning Maud Land, Antarctica, determined by means of airborne radio-echo sounding: Annals of Glaciology, 29, 267-272.

Steinhage, D., Nixdorf, U., Meyer, U., and Miller, H., 2001, Subglacial topography and internal structure of central and western Dronning Maud Land, Antarctica, determined from airborne radio echo sounding: Journal of Applied Geophysics, 47, 183-189.

Studinger, M., Bell, R.E., Blankenship, D.D., Finn, C.A., Arko, R.A., Morse, D.L., and Joughin, I., 2001, Subglacial sediments: A regional geological template for ice flow in West Antarctica: Geophysical Research Letters, 28, 3493-3496.

Studinger, M., Bell, R.E., Buck, W.R., Karner, G.D., and Blankenship, D.D., 2004a, Sub-ice geology inland of the Transantarctic Mountains in light of new aerogeophysical data: Earth and Planetary Science Letters, 220, 391-408.
Studinger, M., Bell, R.E., and Tikku, A.A., 2004b, Estimating the depth and shape of subglacial Lake Vostok's water cavity from aerogravity data: Geophysical Research Letters, 31, Art. No. L12401.

Tabacco, I.E., Bianchi, C., Chiappini, M., Passerini, A., Zirizzotti, A., and Zuccheretti, E., 1999, Latest improvements for the echo sounding system of the Italian radar glaciological group and measurements in Antarctica: Annali Di Geofisica, 42, 271-276.

Tabacco, I.E., Bianchi, C., Zirizzotti, A., Zuccheretti, E., Forieri, A., and Della Vedova, A., 2002, Airborne radar survey above Vostok region, east-central Antarctica: ice thickness and Lake Vostok geometry: Journal of Glaciology, 48, 62-69.

Tabacco, I.E., Passerini, A., Corbelli, F., and Gorman, M., 1998, Determination of the surface and bed topography at Dome C, East Antarctica: Journal of Glaciology, 44, 185-191.

Taylor, J., Siegert, M.J., Payne, A.J., and Hubbard, B., 2004, Regional-scale bed roughness beneath ice masses: measurement and analysis: Computers \& Geosciences, 30, 899-908.

Thomas, R., Rignot, E., Casassa, G., Kanagaratnam, P., and 14 others, 2004, Accelerated sea-level rise from West Antarctica: Science, 306, 255-258.

Tikku, A.A., Bell, R.E., Studinger, M., Clarke, G.K.C., Tabacco, I., and Ferraccioli, F., 2005, Influx of meltwater subglacial Lake Concordia, East Antarctica: Journal of Glaciology, 51, 96-104.

Vaughan, D.G., Corr, H.F.J., Ferraccioli, F., Frearson, N., O'Hare, A., Mach, D., Holt, J.W., Blankenship, D.D., Morse, D.L., and Young, D.A., 2006, New boundary conditions for the West Antarctic Ice Sheet: Subglacial topography beneath Pine Island Glacier: Geophysical Research Letters, 33, Art. No. L09501.

Vaughan, D.G., Corr, H.F.J., Doake, C.S.M., and Waddington, E.D., 1999, Distortion of isochronous layers in ice revealed by ground-penetrating radar: Nature, 398, 323-326.

Welch, B.C., and Jacobel, R.W., 2003, Analysis of deeppenetrating radar surveys of West Antarctica, USITASE 2001: Geophysical Research Letters, 30, 1444.

Wingham, D.J., Siegert, M.J., Shepherd, A., and Muir, A.S., 2006, Rapid discharge connects Antarctic subglacial lakes: Nature, 440, 1033-1036.

Wu, X.L., and Jezek, K.C., 2004, Antarctic ice-sheet balance velocities from merged point and vector data: Journal of Glaciology, 50, 219-230. 